DOI: $10.14746 /$ pi.2021.13.2

\title{
Czwarte życie Irit Amiel
}

\author{
Agata Patalas \\ Szkoła Edukacji Polsko-Amerykańskiej Fundacji \\ Wolności i Uniwersytetu Warszawskiego
}

Są sprawy i zdarzenia, których się nie zapomina. (...)

Niebo zapłonęło łuną palonych ciał, popioły rozsypywano jak kompost na cztery strony świata.

Pisarz, świadek naoczny, opisał - w części zaledwie - widziane.

Jak kronikarz zachował w kilkudziesięciu wycinkach fluid zdarzeń.

M. Frenkel, 1960, To jest morderstwo, książka przełożona przez Irit Amiel na język hebrajski i wydana w 1988 roku

Gdy pracowaliśmy nad tym polsko-żydowskim numerem „Polonistyki. Innowacji”, w swoim domu w Ramat Ganie pod Tel-Awiwem zmarła Irit Amiel, do 1947 roku - roku jej przybycia do Palestyny po ucieczce z Polski dwa lata wcześniej - Irena Librowicz, pisarka i tłumaczka, której książki charakterystycznym dla niej chropawym głosem opowiadają o Zagładzie i jej konsekwencjach trwających do dziś.

Odeszła we śnie nad ranem we wtorek 16 lutego tak, jak zawsze chciała, odwrotnie niż jej rodzice Leon i Natalia, wywiezieni do Treblinki z getta częstochowskiego i zagazowani, niż jej babcia Udl, zepchnięta ze schodów własnego domu i zastrzelona ${ }^{1}$, niż jej koleżanki i koledzy z dzieciństwa: „Moniuś, Lucek, Lejka, Mareczek, Chajka, Lucynka, Lilka, Jurek, Halinka, Dorcia, Szlamek, Rachelka, Zenek, Natasza”, którzy „poszli z dymem przed laty, kiedy wszyscy byli odwróceni”2 ${ }^{2}$.

Po wypchnięciu przez ojca w końcu września 1942 roku z getta na aryjską stronę - miała wtedy 11 lat - przepchnięciu przez otwór w ścianie

\footnotetext{
${ }^{1}$ Amiel I., 2002, Prawa genetyki, w: Wdychać głęboko, Izabelin, s. 16.

${ }^{2}$ Amiel I., 1999, Pożegnanie mojej martwej klasy, w: Osmaleni, Izabelin, s. 83.
} 
komórki, która z drugiej strony była ścianą mieszkania przekupionego granatowego policjanta, najwięcej w ocaleniu zawdzięczała samej sobie: swojej wytrzymałości, intuicji, inteligencji, instynktowi życia, nadto - polskiemu językowi. Mając zaledwie 14 lat, tuż po zakończeniu wojny, zdecydowała o przyłączeniu się do syjonistycznej grupy młodzieży i wyjeździe z Częstochowy, w której „nie czuła się już w życiu jak w domu”3. Po długotrwałej, wyczerpującej podróży - nielegalną drogą przez Austrię, obóz dipisów we Włoszech i internowanie przez Anglików w obozie na Cyprze - nowe życie rozpoczęła w Palestynie, potem Izraelu. Państwo to tworzyła pracą własnych rąk, najpierw w nadmorskim kibucu, potem budując dom poza nim i - jak całe jej wielojęzyczne pokolenie - ucząc się hebrajskiego, który związał tę generację nowym przymierzem. Wiele dla niej znaczył nowy kraj, w którym założyła niemal (Irit napisałaby: „nieomal”) biblijną rodzinę, z biegiem lat zaprzyjaźniając się z sześciorgiem wnucząt i poznając kolejne prawnuczęta. Jej ostatni prawnuk Carmi Raviv urodził się na krótko przed śmiercią babki, bardzo na niego czekała i jest prawie pewne, że to powiązanie istnień i losów umieściłaby, gdyby mogła, w swoim następnym opowiadaniu. Jakby przygotowywała się do tego w listach, gdy niemalże w jednym zdaniu pisała o oczekiwaniu na jego narodziny i własną śmierć, o dobiegłej do mety „sztafecie pokolen”. Rodzinę i Izrael uważała za swoje zwycięstwo nad faszyzmem i antysemityzmem. Miała poczucie, że „zrobiła swoje". Wraz z mężem Chuzym Amiel oraz dziećmi, Oni i Ditą, przez wiele lat pomagała kolejnym olim hadaszim (hebr. nowi przybyli) osiedlić się w żydowskiej ojczyźnie. Była ona dla niej prawdziwym cudem.

Do Polski przyjeżdżała na kilka dni - głównie z okazji publikacji kolejnych książek. Osmaleni (1999), Wdychać głęboko (2002), Podwójny krajobraz (2008), Życie. Tytuł tymczasowy (2014), Spóźniona / Delayed (2016) - opowiadania, wiersze i autobiografię, dla niej wcale nieoddzielne gatunkowo, obierała sobie za literackie medium, wybór ten uzależniając od własnej formy pisarskiej (pierwszą autorską książkę wydała mając 63 lata), od siły oddechu. Czasem do tego, by opowiedzieć los osmalonych, mówić w ich imieniu, potrzebowała zwartego, lapidarnego opowiadania, innym razem kilku, kilkunastu linijek wiersza, w końcu autobiograficznej rozmowy z sobą samą. Wydaje mi się, że najważniejsze pozostało dla niej opowiadanie, w nim najlepiej się czuła, nad nim najbardziej wytrwale pracowała i jemu przypisywała największą moc docierania do odbiorcy, zwłaszcza młodego, na którym jej zależało. Chciała, by kolejne, wchodzące w życie pokolenie, dzięki konfrontacji z prawdą o Zagładzie, "odrobiło lekcję"4 i uodporniło się na antysemicki bakcyl nienawiści, a jednocześnie nie miała złudzeń co do trwałości, wrogiego Żydom i wiecznie powielanego, konstruktu wyobrażeniowego, uprzedzeń i stereotypów, których nie zniszczyła żadna z wojen, żywych również z powodu zalęknionej, złej szkolnej edukacji.

${ }^{3}$ Amiel I., Kartka z pamiętnika, s. 9.

4 „Zrobiłam swoje” i „żeby Polacy odrobili lekcję” - te sformułowania Irit Amiel powtarzała przy różnych okazjach. 
Zawsze starała się opowiadać „na poziomie oczu czytelnika” ${ }^{5}$ i warto zauważyć, że gdy się dziś ogląda pozostałe po wieczorach autorskich materiały filmowe, na twarzach publiczności widać napięcie i koncentrację, a w oczach ludzi nieraz łzy. Mówiła im prosto w oczy rzeczy, jakich się nie spodziewali usłyszeć, rozrywała tabu i z uwagą, a nawet empatycznym wychyleniem, obserwowała reakcje. Wiele razy wychodziła z tej konfrontacji z poczuciem obcości i braku porozumienia. Jednocześnie jej twórczość miała siłę osmalenia czytelnika zarówno doświadczeniami zgładzonych i ocalałych, jak przedłużonym i odwróconym językiem piekielnego ognia. Ze względu na swoje praktyczne nastawienie do pracy literackiej nigdy by tego nie nazwała gestem etycznym, wolała raczej mówić o tym, co jest winna tym, którzy sami nie mogą mówić, i bardzo uważała, by odzywać się „skromnie i cicho”, bez jednej nuty fałszu. Do swoich przeżyć dodawała doświadczenia zapożyczone z rozmów z innymi ocalałymi osmalonymi, tworząc międzygatunkowy literacki patchwork. Lubiła rozmawiać z ludźmi w otwarty sposób, ubytki słuchu, które wcześnie zaczęły dawać jej się we znaki, zastępując uważnością, zaangażowanym wsłuchiwaniem się w drugą osobę całym umysłem i ciałem. Bardzo uważała, by pozostać uczciwą wobec wszystkich - tych, którzy cudem przeżyli i powierzyli jej swoje historie, i tych, którzy zostali zamordowani. Czasem nie było to łatwe, zwłaszcza wtedy, gdy obie te perspektywy wykluczały się czy też pozostawały w ostrym konflikcie. Wtedy milkła i odkładała długopis.

Możliwe, że nie wiemy jeszcze, co tak naprawdę pozostawiła po sobie Irit Amiel. Jej twórczość dopiero zaczyna być głębiej odczytywana. Nie wiadomo, w którą stronę pójdą interpretacje i czy to będzie bliska jej strona. Na artykuły, omawiające wiersze i opowiadania, patrzyła jak Gombrowicz na inscenizacje teatralne swoich dramatów, zadając pytanie: czy to jeszcze ja? I - co ważniejsze - czy to jeszcze ja i oni, bezlitośnie i najbrutalniej osmaleni? Pierwszym przekładem Osmalonych na język obcy była węgierska wersja książki. Irit brała ją do ręki i śmiała się wtedy, że i tak nikt nie wie i nigdy wiedział nie będzie, co tak naprawdę jest w środku. Bardzo się cieszyła z tłumaczeń i nowych czytelników, zasiedlających coraz więcej mieszkań wieży Babel. Chętnie odwiedzała ich kraje, jeździła na wieczory autorskie i próbowała własnym głosem jeszcze raz wskrzesić postaci z kartek i z popiołów. Odczuwała to jako moralny nakaz, który jednocześnie zasilał jej pisarską motywację przez kilkadziesiąt lat, aż do samego końca.

Gdy się myśli o końcu jej życia tutaj, popada się w podziw i zdumienie. Irit Amiel bardzo pracowicie, świadomie i długo przygotowywała się do śmierci. Starzenie się przeżywała nie mniej głęboko niż swój czas dojrzały. Znałyśmy się przez ćwierć wieku i zawsze o starości i śmierci wspominała. Tę ostatnią wykurzała ze swojego domu, kazała się przesiadać, stawiała po kątach, podczas jedzenia posiłków trzymała z daleka, choć wiedziała

${ }^{5}$ Amiel I., 2002, Przedmowa, w: Wdychać głęboko, s. 7.

${ }^{6}$ Tamże. 
oczywiście, że każda chwila życia dzieje się na prawach śmierci i że to ona gra jej i nam do tańca. Gdy już nie mogła zrealizować do końca żadnego ze swych nowych pomysłów na opowiadania, a ciągle szukała sposobów na pisanie w starości, coraz ambitniejszych i trudniejszych w praktyce, próbowała wracać do tłumaczeń jak wtedy, gdy zaczynała swoją pisarską drogę. Chciała podarować polskiemu językowi hebrajską wyobraźnię. Koło się domykało, aż w końcu zamknęło, i Irit dołączyła do „mniej zmarłych” swoich bohaterów, czyniąc ich „bardziej zmarłymi”, tak jak to przewidziała w jednym ze swoich wierszy ${ }^{7}$. Już nie dopowie ich losów. Zostaliśmy z nimi całkiem sami, ale z jej niewytartymi słowami w gardle.

Pierwsze życie Irit Amiel zaczęło się przy jej narodzinach. Drugie po wyjściu z getta. Trzecie po osiedleniu w Izraelu. Teraz rozpoczęło się ostatnie - czwarte.

${ }^{7}$ Amiel I., Mniej zmarli, s. 12. 